Table 2 Reasons for stopping topical g.CsA $1 \mathrm{mg} / \mathrm{ml}$

\begin{tabular}{llll}
\hline $\begin{array}{l}\text { Person deciding to } \\
\text { discontinue treatment }\end{array}$ & Reason for discontinuation & $n$ & $\%$ \\
\hline Family/child & Resolution of symptoms & 6 & 12 \\
& $\begin{array}{l}\text { Stinging on instillation, eyes } \\
\text { felt worse }\end{array}$ & 2 & 4 \\
& $\begin{array}{l}\text { Reason not documented } \\
\text { Resolution of symptoms/ }\end{array}$ & 9 & 18 \\
& $\begin{array}{l}\text { Improvement of signs } \\
\text { Ophthalmologist }\end{array}$ & 10 & \\
& $\begin{array}{l}\text { Patient intolerance } \\
\text { No improvement in response }\end{array}$ & 3 & 6 \\
& to treatment & & \\
\hline
\end{tabular}

neoplasia, although the previous data for other preparations used for over 30 years indicate that the risk of serious adverse events is minimal and unproven [4].

Based on this study, our first cases and continuing experience in using the new preparation, topical CsA appears safe and highly effective for disease control and as a steroid-sparing agent in chronic ocular surface inflammation in children at a dose of between two and four times daily. The lack of licence for this age group and indication leads to difficulties accessing it from non-specialist units and as repeat prescriptions in primary care. A randomized controlled trial of g.CsA $1 \mathrm{mg} / \mathrm{ml}$ in children with $\mathrm{VKC}$ has recently been completed [5], and licensing for this indication and age group will permit wider use.

Acknowledgements We would like to thank Esther Papamichael, Kunal Gadhvi, and Deepan Vetpillai for their help in collecting data.
The research was supported by the National Institute for Health Research (NIHR) Biomedical Research Centre based at Moorfields Eye Hospital NHS Foundation Trust and UCL Institute of Ophthalmology. The views expressed are those of the authors and not necessarily those of the NHS, the NIHR, or the Department of Health. AH Dahlmann-Noor is a medical advisor to Santen Inc.

\section{Compliance with ethical standards}

Conflict of interest The authors declare that they have no conflict of interest.

\section{References}

1. Hingorani M, Moodaley L, Calder VL, Buckley RJ, Lightman S. A randomized, placebo-controlled trial of topical cyclosporin $\mathrm{A}$ in steroid-dependent atopic keratoconjunctivitis. Ophthalmology. 1998;105:1715-20.

2. Leonardi A. Management of vernal keratoconjunctivitis. Ophthalmol Ther. 2013;2:73-88.

3. O'Gallagher $M$, Bunce C, Hingorani $M$, Larkin F, Tuft S, Dahlmann-Noor A. Topical treatments for blepharokeratoconjunctivitis in children. Cochrane Database Syst Rev. 2017;2: CD011965.

4. Flynn TH, Manzouri B, Tuft SJ. Ocular surface squamous neoplasia in an immunosuppressed patient with atopic keratoconjunctivitis. Int Ophthalmol. 2012;32:471-3.

5. Leonardi A, Doan S, Amrane M, Ismail D, Montero J, Rao V, et al. Topical Ciclosporin A $1 \mathrm{mg} / \mathrm{mL}$ cationic emulsion in the treatment of active severe vernal keratoconjunctivitis (VKC) in pediatric patients: results of the phase III VEKTIS study. Invest Ophthalmol Vis Sci. 2017;58:541.

\title{
Comment on: 'An international comparison of retinopathy of prematurity grading performance within the Benefits of Oxygen Saturation Targeting II trials'
}

\author{
F. R. Burgess $\mathbb{D}^{1} \cdot$ R. Davies $^{1} \cdot$ A. O. Mulvihill ${ }^{1} \cdot$ C. L. L. Schmoll ${ }^{1}$
}

Received: 21 February 2018 / Accepted: 5 March 2018 / Published online: 3 April 2018

(c) The Royal College of Ophthalmologists 2018

\author{
F. R. Burgess \\ Frederick.burgess@nhslothian.scot.nhs.uk \\ Princess Alexandra Eye Pavilion, Edinburgh, UK
}

Fleck et al. have noted international differences in interobserver variation in ROP grading and management between UK and Australian/New Zealand (ANZ) ophthalmologists [1, 2]. 
Eight consultant ophthalmologist ROP screeners in Scotland graded RetCam (Natus Medical, Pleasanton, CA, USA) images of 25 eyes of 25 infants regarding the presence and severity of plus disease, and stated their management decision ('treatment' or 'no treatment'). Clinical information on gestational age at birth, birth weight, and post-gestational age at the time of imaging was provided. Graders viewed the revised standard ICROP photograph for plus disease prior to commencing the task [3]. Thirteen of the 25 eyes were treated for ROP.

Inter-observer agreement (Fleiss-Kappa, where $0.21-0.40$ is considered 'fair') was 0.34 (95\% CI $=$ $0.28-0.39)$ for the presence of plus and $0.40(95 \% \mathrm{CI}=$ $0.33-0.48$ ) for management decision, slightly greater than that reported by Fleck et al. for UK ophthalmologists $(0.2$ and 0.33 , respectively) [2].

Our data supports the poorer degree of inter-observer agreement found for UK ophthalmologists compared with those of the ANZ group, who had lower treatment rates, although comparable visual outcomes, in the BOOST II trials [4]. The ANZ grading group self-certified using a training website. Given that a possible tendency towards over-treating ROP could result in unnecessary morbidity, the development of a similar online tool to improve standardisation and management decisions would be of potential benefit to UK ophthalmologists.

\section{Compliance with ethical standards}

Conflict of interest The authors declare that they have no conflict of interest.

\section{References}

1. Chiang MF, Jiang L, Gelman R, Du YE, Flynn JT. Interexpert agreement of plus disease diagnosis in retinopathy of prematurity. Arch Ophthalmol. 2007;125:875-80.

2. Fleck BW, Williams C, Juszczak E, Cocker K, Stenson BJ, Darlow BA, Dai S, Gole GA, Quinn GE, Wallace DK, Ells A, Carden S, Butler L, Clark D, Elder J, Wilson C, Biswas S, Shafiq A, King A, Brocklehurst P, Fielder AR, for the BOOST II Retinal Image Digital Analysis (RIDA) Group. An international comparison of retinopathy of prematurity grading performance within the Benefits of Oxygen Saturation Targeting II trials. Eye. 2018;32:74-80.

3. International Committee for the Classification of Retinopathy of Prematurity. The international classification of retinopathy of prematurity revisited. Arch Ophthalmol. 2005;123:991-9.

4. Australia5 B-I, United Kingdom Collaborative Group, TarnowMordi W, Stenson B, Kirby A, Juszczak E, et al. Outcomes of two trials of oxygen-saturation targets in preterm infants. N Engl J Med. 2016;374:749-60. 